\title{
Effect of Intracellular Injection of Inositol Trisphosphate on Cytosolic Calcium and Membrane Currents in Aplysia Neurons
}

\author{
Simon Levy \\ Department of Physiology, Boston University School of Medicine, Boston, Massachusetts 02118
}

Pacemaker cells of Aplysia californica display a regular bursting that results from a complex interplay of $\mathrm{Ca}^{2+}-\mathrm{me-}$ diated conductances and a continuous influx and extrusion of $\mathrm{Ca}^{2+}$. The effect of the second messenger 1,4,5-inositol trisphosphate (Ins $\mathrm{P}_{3}$ ) on intracellular free $\mathrm{Ca}^{2+}$ concentration $\left(C a_{i}\right)$ regulation and electrical properties was investigated in identified neurons of the abdominal ganglion (R15, L2-L4, L6). Double-barreled $\mathrm{Ca}$-selective microelectrodes were used to pressure inject Ins $\mathrm{P}_{3}$ and measure $\mathrm{Ca}_{i}$ at the same point. Brief injection of $\operatorname{lns} \mathrm{P}_{3}$ resulted in an average increase of $\mathrm{Ca}$, of $9.2 \pm 10.0 \mu \mathrm{M}( \pm S E ; n=14)$ that decayed in about $1 \mathrm{~min}$. The Ins $\mathrm{P}_{3}$-induced elevation of $\mathrm{Ca}_{i}$ increased in a dose-dependent manner and saturated when large amounts of Ins $\mathrm{P}_{3}$ were injected. The $\operatorname{lns} \mathrm{P}_{3}$-induced $\mathrm{Ca}_{i}$ increase was the result of mobilization from intracellular stores; $\mathrm{Ca}_{i}$ could be repeatedly mobilized by Ins $P_{3}$ in cells superfused with 0 Ca artificial seawater for more than $60 \mathrm{~min}$. Following multiple injections of InsP $P_{3}$, there was no evidence of immediate inhibition or facilitation. The spatial nature of the Ins $_{3}$-induced $\mathrm{Ca}_{i}$ increase was investigated by moving the doublebarreled Ca-selective microelectrode tip in a stepwise manner relative to the membrane surface. The largest Ins $\mathrm{P}_{3}$ induced $\mathrm{Ca}_{i}$ increases were measured in an area $0-80 \mu \mathrm{m}$ from the membrane surface; some cells had their largest Ins $\mathrm{P}_{3}$-induced $\mathrm{Ca}_{3}$ increase some $120-160 \mu \mathrm{m}$ away from the membrane. Injection of $\operatorname{lns}_{3}$ in a bursting neuron induced an immediate train of action potentials followed by membrane hyperpolarization and a decrease in the burst frequency. Injection of Ins $\mathrm{P}_{3}$ in voltage-clamped celis induced a biphasic response: a rapid inward current followed by a more prolonged outward current; the temporal overlap of the currents was depth dependent. Injection of $\operatorname{Ins}_{3}$ or $\mathrm{Ca}^{2+}$ from a double-barreled injecting electrode induced currents that were different in waveform and time course, indicating that part of the conductance change induced by Ins $P_{3}$ is direct and not mediated by the mobilized $\mathrm{Ca}^{2+}$. In BAPTA [1,2-bis(2-aminophenoxy)ethane- $N, N, N^{\prime}, N^{\prime}$ tetra-acetic acid]-loaded cells, the Ins $\mathrm{P}_{3}$-induced inward current was mostly unaffected while the Ca-induced outward current was

\footnotetext{
Received May 22, 1991; revised Jan. 6, 1992; accepted Jan. 9, 1992.

This work was supported by Grant NSF-BNS 88220001 and Whitaker Health Science Fund. I thank Dr. Péter Enyedi for samples of Ins $(2,4,5) \mathrm{P}_{3}$ and Ins $(1,3,4,5) \mathrm{P}_{4}$, and Drs. Enrico Nasi and Gregor Jones for help with the software. I am grateful to Drs. Richard Payne, Enrico Nasi, and Gregor Jones for helpful discussions.

Correspondence should be addressed to Simon Levy, Ph.D., Department of Physiology, L-719, Boston University School of Medicine, Boston, MA 02118.

Copyright (C) 1992 Society for Neuroscience $0270-6474 / 92 / 122120-10 \$ 05.00 / 0$
}

largely attenuated. The results suggest that $\ln \mathbf{P}_{3}$ mobilizes $\mathrm{Ca}^{2+}$ from discrete intracellular compartments and induces distinct changes in membrane currents that seem to be independent of the $\mathrm{Ca}_{i}$ increase.

The bursting pattern displayed by molluscan pacemaker cells appears to result from a complex interplay of $\mathrm{Ca}^{2+}$-mediated conductances and a continous accumulation and extrusion of $\mathrm{Ca}^{2+}$ (Gorman ct al., 1981; Adams, 1985; Kramer and Zucker, $1985 \mathrm{a}, \mathrm{b})$. The $\mathrm{Ca}^{2+}$ that accumulates with membrane activity was shown to be implicated in the gating mechanisms of two membrane conductance systems. One is a membrane channel system selectively permeable to $\mathrm{K}^{+}$whose conductance depends on the level of intracellular free $\mathrm{Ca}^{2+}$ concentration $\left(\mathrm{Ca}_{i}\right)(\mathrm{Meech}$, 1974; Gorman and Hermann, 1979; see, however, Adams and Levitan, 1985; Kramer and Zucker, 1985a,b). The other is the Ca conductance system, whose inactivation appears to be mediated by accumulated $\mathrm{Ca}^{2+}$ (Tillotson, 1979).

In view of the sensitivity of these membrane conductances to intracellular $\mathrm{Ca}^{2+}$, second messengers like 1,4,5-inositol trisphosphate $\left(\mathrm{Ins}_{3}\right)$ may have important effects on membrane currents and $\mathrm{Ca}_{i}$ regulation in nerve cells. There is also evidence that the bursting activity of pacemaker neurons can be modulated by several neurotransmitters and neuropeptides (Levitan et al., 1979; Smith, 1980); some of these neurotransmitters were found to exert their action on membrane channels through variations in cAMP, or independently of it (Levitan, 1985). It is unknown whether any of these neurotransmitters mobilize $\mathrm{Ca}_{i}$. It is also unclear what would be the advantages of mobilized $\mathrm{Ca}_{i}$ in addition to the well-characterized $\mathrm{Ca}^{2+}$ influx/Ca conductance system. One possibility would be for the $\mathrm{Ca}$ signal resulting from the opening of voltage-activated $\mathrm{Ca}^{2+}$ channels to be amplified by mobilization of $\mathrm{Ca}_{i}$ through $\mathrm{Ca}$-dependent formation of InsP $\mathrm{P}_{3}$ (Eberhard and Holz, 1988; Harootunian et al., 1991). An added advantage would be to segregate entering and mobilized $\mathrm{Ca}^{2+}$ because they may have different target molecules.

In the present study, I have investigated the effect of InsP on $\mathrm{Ca}_{i}$ regulation and electrical properties of Aplysia neurons from the abdominal ganglion. Using double-barreled Ca-selective microelectrodes, I found that brief intracellular injections of InsP $\mathrm{P}_{3}$ mobilize $\mathrm{Ca}_{i}$ from intracellular stores. Moreover, I tried to dissociate its $\mathrm{Ca}^{2+}$ mobilization role from its direct action on the membrane conductance by injecting InsP $\mathrm{P}_{3}$ and $\mathrm{Ca}^{2+}$ side by side at the same point. I found that Ins $\mathrm{P}_{3}$ induces changes in membrane currents that are distinct from the ones induced by $\mathrm{Ca}^{2+}$ injections. 
Some of the results have becn reported previously in abstract form (Levy, 1987, 1988, 1989).

\section{Materials and Methods}

Preparation. Specimens of Aplysia californica (200-300 gm) were obtained from Alacrity Marine Biological Services (Redondo Beach, CA) and kept in artificial seawater (Instant Ocean, Mentor, $\mathrm{OH}$ ) at $14-16^{\circ} \mathrm{C}$. Experiments were performed on identified neurons (R15, L2-L4, L6) of the abdominal ganglion (Frazier et al., 1967), known to have substantial Ca currents. Some injections were made in R2 cells. The methods for dissecting and recording have appeared previously (Gorman et al., 1984). Briefly, the abdominal ganglion was dissected out of the animal, treated with protease (Pronase, Calbiochem, San Diego, CA; $5-7 \mathrm{mg}$ in $2 \mathrm{ml}$ of seawater for $20 \mathrm{~min}$ at room temperature), and then pinned to the bottom of a $1 \mathrm{ml}$ recording chamber and desheathed. Ganglia were continuously superfused with normal artificial seawater (NSW) having the following composition (in mM: $\mathrm{NaCl}, 500 ; \mathrm{KCl}, 10$; $\mathrm{CaCl}_{2}, 10 ; \mathrm{MgCl}_{2}, 50$; and Tris. $\mathrm{HCl}, 10, \mathrm{pH} \mathrm{7.8).} \mathrm{In} 0 \mathrm{Ca}$ artificial seawater ( $0 \mathrm{Ca}-\mathrm{SW}$ ) solutions, $\mathrm{Mg}^{2+}$ was substituted for $\mathrm{Ca}^{2+}$ and $2 \mathrm{mM}$ EGTA [ethyleneglycol-bis-( $\beta$-aminoethylether)- $N, N^{\prime}$-tetra-acetic acid] were added. Experiments were carried out at about $18^{\circ} \mathrm{C}$.

Injections. I intracellularly injected the following solutions: $10 \mu \mathrm{M}$ to 1 mM D-myo-inositol 1,4,5-trisphosphate (Sigma, St. Louis, MO); 100 $\mu \mathrm{M}$ Ins $(2,4,5) \mathrm{P}_{3}$ (Calbiochem, San Diego, CA); $100 \mu \mathrm{M} \operatorname{Ins}(1,3,4,5) \mathrm{P}_{4}$ (Calbiochem); 1 mм myo-inositol (Sigma); $10 \mathrm{~mm} \mathrm{CaCl}_{2} ; 100 \mathrm{~mm}$ BAPTA [1,2-bis(2-aminophenoxy)ethane- $N, N, N^{\prime}, N^{\prime}$-tetra-acetic acid; Molecular Probes, Eugene, OR]. Except as noted, all substances were dissolved in a carrier solution containing $200 \mathrm{mM} \mathrm{K}$-acetate and $20 \mathrm{mg} /$ $\mathrm{ml}$ of a red dye (Reactive Red, Sigma). To prevent contamination of the injection barrel by $\mathrm{Ca}^{2+}$, the following precautions were taken: (1) the $\mathrm{K}$-acetate solution was passed through a chelating ion-exchange resin (Chelex-100, Bio-Rad, Richmond, CA); (2) the injection barrel stayed a very short time in the bathing solution (NSW has $10 \mathrm{mM} \mathrm{Ca}^{2+}$ ) prior to impalement; (3) in some experiments insertion of the injection electrode was made in $0 \mathrm{Ca}-\mathrm{SW}$. The red dye served as a visual marker to monitor successful injections. Pressure injection with this dye was easily seen both in the bath and inside the cell. I found that I could reliably inject solutions intracellularly if I could first visualize ejection of the red solution in the bath prior to inserting the electrode. I carefully checked that pressure injections did result in ejection of a red dot inside the cell. Control injections in the bath were always made after withdrawal of the injection electrodes from the cell.

Most intracellular injections were made from double-barreled microelectrodes made from $\Theta$-glass capillaries (style $1 \mathrm{~A}, \mathrm{R} \& \mathrm{D}$ Glass Co., Spencerville, MD). One barrel was typically used to pressure inject the substance of choice while the adjacent barrel, selective to $\mathrm{Ca}^{2+}$, was used to measure the resulting $\mathrm{Ca}_{i}$ change at the same location (see below and Fig. 1 $A$ ). Alternatively, the adjacent barrel was used to inject a different substance so side-by-side comparison of effects on membrane currents could be made. Rapid injections were achicved by applying brief pressure pulses using a programmable pulse generator (Ionoptix Instruments, Milton, MA) and an electropneumatic valve (Clippard, Cincinnati, $\mathrm{OH}$ ). The output of the pulse generator was connected to the chart recorder and was used to monitor the timing of the pressure pulse (stimulus monitor). To estimate the amount injected, I routinely made injections into an oil droplet or in air and measured the diameter of the droplet (Corson and Fein, 1983). A rather large injection (70 psi, $2 \mathrm{sec}$ ) ejected about $40 \mathrm{pl}$, which amounts to $0.3-0.9 \%$ of the cell volume for cells $200-300 \mu \mathrm{m}$ in diameter. Intracellular injections ranged from $32 \mathrm{psi} / 0.1 \mathrm{sec}$ to $70 \mathrm{psi} / 2 \mathrm{sec}$. Injections were made at different depths within the cell by moving the injection electrode by steps of 5-15 $\mu \mathrm{m}$ using a Huxley-type micromanipulator (Custom Medical Research Equipment, Glendora, NJ).

$C a_{\mathrm{i}}$ measurement. Measurements of $\mathrm{Ca}_{i}$ were made using $\mathrm{Ca}$-sensitive microelectrodes of the membrane type in which a column of sensor selective to $\mathrm{Ca}^{2+}$ is contained in the open tip of a glass micropipette. The sensor mixture (Fluka 21048, Ronkonkoma, NY), based on the ligand ETH 1001 (Oehme et al., 1976), was made syrupy by adding polyvinyl chloride (13-16\%) and tetrahydrofuran (Aldrich, Milwaukee, WI). Double-barreled Ca-selective microelectrodes were used. The aim was to make point injections with one barrel and measure the resulting change in $\mathrm{Ca}$ with the adjacent $\mathrm{Ca}^{2+}$-selective barrel (Fig. $1 \mathrm{~A}$ ). One advantage is that I can make spatial measurements by moving the electrode tip within the cell (Gorman et al., 1984). The fabrication of
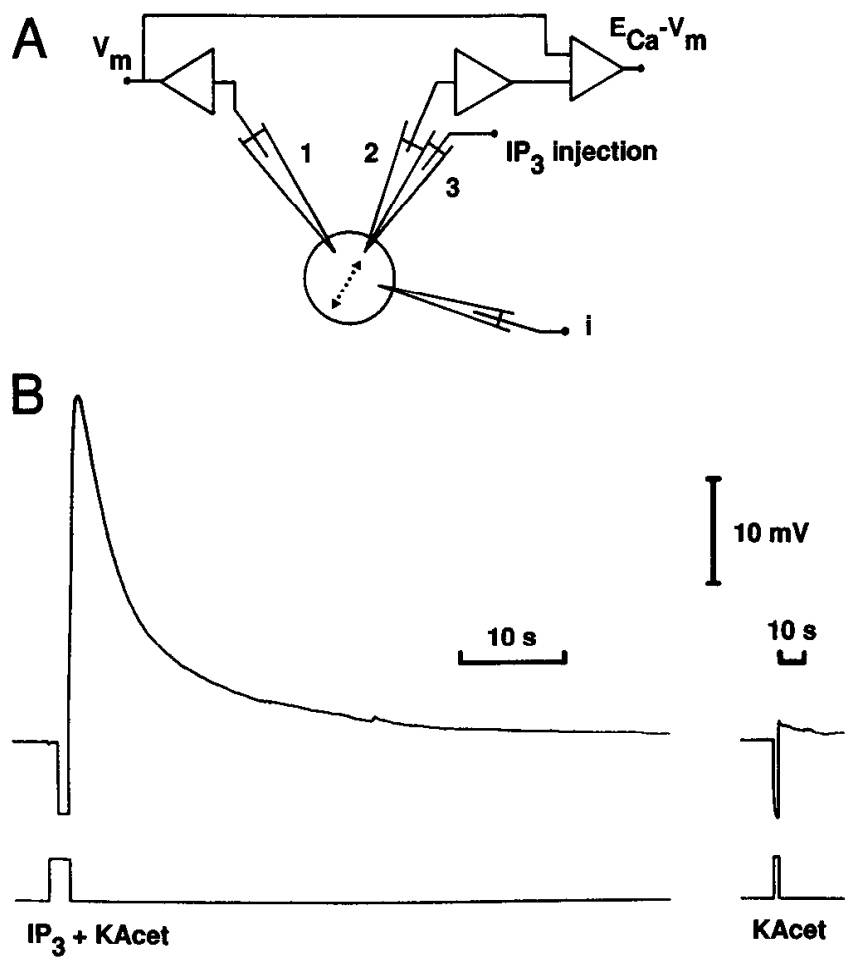

Figure 1. A, Schematic diagram of the experimental arrangement for directly measuring Ins $\mathrm{P}_{3}$-induced $\mathrm{Ca}$ increases. The nerve cell is impaled with voltage (electrode 1 ) and current passing $(i)$ electrodes. The doublebarreled $\mathrm{Ca}$ electrode is inserted and advanced or withdrawn in 5-15 $\mu \mathrm{m}$ increments. At each increment, Ins $\mathrm{P}_{3}$ is pressure injected through the nonactive barrel (electrode 3 ) and measured at the same point with the adjacent Ca-sensitive barrel (electrode 2 ). Intracellularly, $V_{m}$ is subtracted from the voltage measured by the $\mathrm{Ca}$ electrode to yield the differential Ca signal $\left(E_{\mathrm{Ca}}-V_{m}\right)$. In turn, the Ca signal is converted to $\mathrm{Ca}^{2+}$ concentrations using a calibration curve. $B$, Typical InsP ${ }_{3}$-induced $\mathrm{Ca}$ signal increase and control injection of carrier solution. The top trace is the differential Ca signal; the lower trace is the stimulus monitor (command voltage to the electropneumatic valve). Left panel, the double-barreled Ca electrode contained $10 \mu \mathrm{M} \mathrm{InsP}{ }_{3}$ and $20 \mathrm{mM} \mathrm{K}$-acetate. A 2-sec-long pressure injection through the Ins $\mathrm{P}_{3}$ barrel (55 psi) resulted in a negative-going signal followed by a large $\mathrm{Ca}$ signal measured by the $\mathrm{Ca}$ electrode. The corresponding $\mathrm{Ca}_{i}$ increase was about $5 \mu \mathrm{M}$. The $\mathrm{Ca}_{i}$ increase returned to baseline within $50 \mathrm{sec}\left(t_{1 / 2}=5 \mathrm{sec}\right)$. Right panel, the same cell was then impaled with a different double-barreled $\mathrm{Ca}$ electrode containing only the carrier solution. In response to a similar 2-sec-long pressure injection (40 psi), the Ca signal consisted mostly of a negative-going potential.

double-barreled Ca-selective microelectrodes is essentially as described by Munoz et al. (1983). After silanization using TMSDMA ( $N, N$-Dimethyltrimethylsilylamine; Fluka 41720 ) at $250^{\circ} \mathrm{C}$, the tip of the doublebarreled microelectrode is beveled to $2-3 \mu \mathrm{m}$. The active barrel is backfilled with a Ca-buffered solution (about $0.5 \mu \mathrm{M}$ free $\mathrm{Ca}^{2+}, 300 \mathrm{mM} \mathrm{KCl}$ ) and filled with sensor by dipping the tip and using suction. The columns of sensor are usually $30-100 \mu \mathrm{m}$ long. The resistance of the Ca-sensitive barrel is usually $50-500 \mathrm{G} \Omega$.

The response time of the Ca microelectrodes was routinely measured using a fast solution change system described elsewhere (Levy and Fein, 1985; Levy and Tillotson, 1987). Following a step change in $\mathrm{Ca}^{2+}$ concentration from $0.1 \mu \mathrm{M}$ to $1 \mu \mathrm{M}$, Ca electrodes typically reach $50 \%$ and $90 \%$ of their final potential in about $100 \mathrm{msec}$ and $1.5 \mathrm{sec}$, respectively. The time to peak as well as the magnitude of the $\mathrm{InsP}_{3}$-induced $\mathrm{Ca}$ signals measured in this study is most probably affected by the response time of the $\mathrm{Ca}$ electrodes. The falling phase of several seconds is, however, unlikely to be affected. For an extensive discussion of the dynamic response of Ca electrodes, see Levy and Tillotson (1987).

The calibration of the Ca-sensitive barrel and the composition of the calibrating solutions are described in detail elsewhere (Levy and Fein, 
A

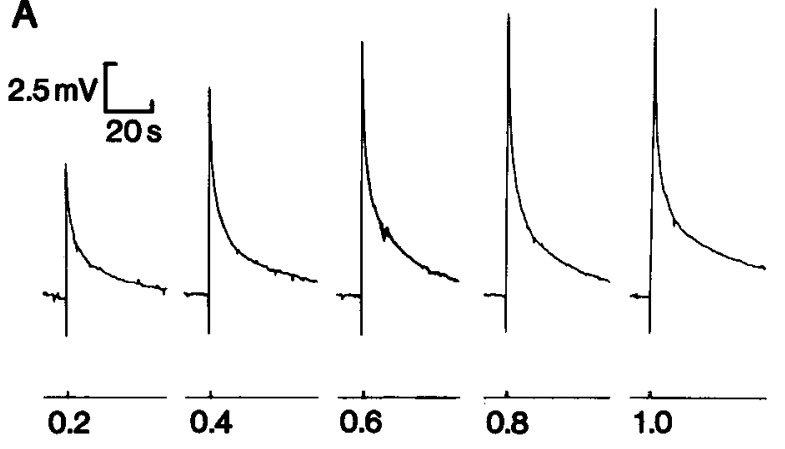

B

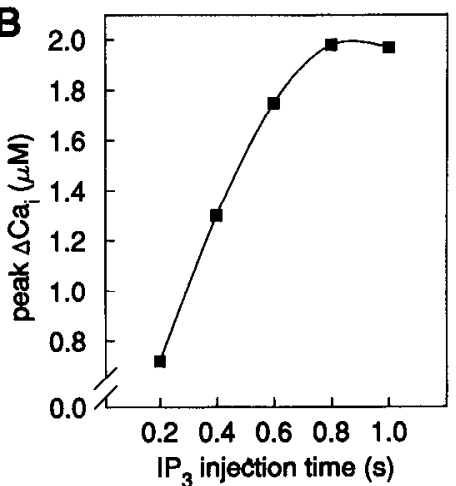

Figure 2. Dependence of InsP $\mathrm{P}_{3}$-induced $\mathrm{Ca}_{i}$ increase on $\mathrm{InsP}_{3}$ concentration. $A$, Effect of pressure pulse duration on the amplitude of the InsP $\mathrm{P}_{3}$ induced $\mathrm{Ca}_{i}$ increase in an $\mathrm{R} 15$ cell (same experimental arrangement as in Fig. $1 A$ ). Top trace, differential Ca signal; bottom trace, stimulus monitor. The pulse duration $(\mathrm{sec})$ is shown under each trace. The measured $\mathrm{Ca}$ signal increases monotonically with increasing pulse durations. The time intervals following each injection were, respectively, $68 \mathrm{sec}$ after the 0.2 injection, $104 \mathrm{sec}$ after the $0.4,112 \mathrm{sec}$ after the 0.6 , and $160 \mathrm{sec}$ after the 0.8 injection. $B$, plot of the peak $\Delta \mathrm{Ca}_{i}$ versus pressure pulse durations taken from $A$ to show that the increase in Ca $\mathrm{Ca}_{i}$ saturates at longer pulse

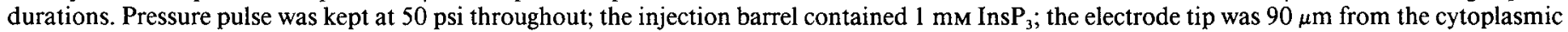
membrane.

1985; Levy and Tillotson, 1988). Although the ion-sensitive electrodes measure activities, the values are expressed as the intracellular free ion concentrations. The activity coefficient should remain constant on the assumption that the extracellular medium has approximately the same ionic strength as the intracellular one and the calibrating solutions.

Electrical arrangement. Figure $1 A$ shows a schematic diagram of the recording system. The $\mathrm{Ca}$ microelectrode potential $\left(E_{\mathrm{Ca}}\right)$ was recorded by a custom-built high-input impedance electrometer (Pelagic Instruments, Falmouth, MA) based on the AD515L operational amplifier (Analog Devices, Norwood, MA). A separate intracellular voltage electrode was used to measure the cell's membrane potential $\left(V_{m}\right)$. The potential of the $V_{m}$ electrode was subtracted from that of the Ca-sensitive barrel to give the Ca signal, $E_{\mathrm{Ca}}-V_{m}$, which is a measure of $\mathrm{Ca}_{i}$. In most experiments, a current-passing electrode was also inserted into the cell in order to voltage clamp the nerve cells. Both the $V_{m}$ and the current electrode were filled with $3 \mathrm{M} \mathrm{KCl}$ and had resistances of 2-5 MS. A bath electrode was connected to an $I-V$ converter having a 5 $\mathrm{M} \Omega$ feedback resistor and was used to measure the total membrane current $\left(I_{m}\right)$. Unless otherwise noted, all cells were voltage clamped at $-45 \mathrm{mV} . V_{m}, I_{m}$, the stimulus monitor, and the $\mathrm{Ca}$ signal were recorded continuously on a multichannel recorder (Gould, Cleveland, $\mathrm{OH}$ ). The Ca signal recorded and shown on all figures was filtered by a $5 \mathrm{~Hz}$ lowpass filter. In some experiments, the Ca signal, $V_{m}, I_{m}$, and stimulus monitor were also recorded (16 bit resolution) using a PCM recording adaptor (Unitrade DAS 601, Dagan, Minneapolis, MN) for subsequent playback and analysis.

Injection artifacts. Figure $1 B$ shows an Ins $\mathrm{P}_{3}$-induced $\mathrm{Ca}_{i}$ increase in an $\mathrm{L} 2$ cell. In response to injected $\mathrm{InsP}_{3}$, the Ca signal consisted of a fast negative-going potential followed by a positive-going potential with a time to peak of about $1 \mathrm{sec}$ (left panel). The Ca signal increase corresponded to a $\mathrm{Ca}_{i}$ increase of about $5 \mu \mathrm{M}$. The $\mathrm{Ca}_{i}$ increase recovered within $50 \mathrm{sec}$ with a half-time of about $5 \mathrm{sec}$. Pressure injection of the carrier solution alone, in the same cell, resulted in a Ca signal consisting mostly of the negative-going potential; this indicated that the negativegoing potential was an injection artifact (right panel). Extensive control injections were made in solutions of different ionic content and $\mathrm{Ca}$ buffering capacities. Control injections of $\operatorname{InsP}_{3}$, usually made before insertion into cells, always resulted in an injection artifact in all solutions tested. In some cases, the injection artifact consisted of a fast negativegoing followed by a fast positive-going signal; this type of injection artifact differed from a normal InsP $\mathrm{P}_{3}$-induced $\mathrm{Ca}_{i}$ increase in two respects. Its entire time course only lasted the length of the pressure pulse and its amplitude or time course did not change when control injections were made in solutions of different $\mathrm{Ca}$ buffering capacities. By contrast, the Ins $\mathrm{P}_{3}$-induced $\mathrm{Ca}$ signal changes seen intracellularly outlasted the pressure pulse by about 1 min (Figs. 1-4). Another evidence that the injection artifact cannot explain the normal Ins $P_{3}$-induced $\mathrm{Ca}_{i}$ increase can be seen in Figure 3: the Ca signal amplitude, following a standard Ins $P_{3}$ injection, depends strongly on the spatial location of the doublebarreled Ca-selective microelectrode.

\section{Results}

The Ins $P_{3}$-induced increase in $\mathrm{Ca}_{\mathrm{i}}$

The range for the peak $\mathrm{Ca}_{i}$ increase in 14 cells varied from 0.34 to $35.5 \mu \mathrm{M}$. Three cells (all from the same ganglion) had no measurable Ins $\mathrm{P}_{3}$-induced $\mathrm{Ca}_{i}$ increase. The peak $\mathrm{Ca}_{i}$ increase refers here to the one generally measured at the site of highest $\mathrm{InsP}_{3}$-induced $\mathrm{Ca}_{i}$ increase (see Spatial variations of the $\mathrm{InsP}_{3}$ induced $\mathrm{Ca}_{i}$ increase, below).

The Ins $\mathrm{P}_{3}$-induced elevation of $\mathrm{Ca}_{4}$ increased in a dose-dependent manner. Figure $2 A$ shows a series of $\mathrm{Ca}_{i}$ increases induced by brief injections of $\mathrm{InSP}_{3}$ of increasing durations in an $\mathrm{R} 15$ cell. The peak $\mathrm{Ca}_{i}$ increased monotonically with increasing pulse durations, and eventually saturated as large amounts of $\mathrm{InsP}_{3}$ were injected. Figure $2 \mathrm{~B}$ shows a plot of the peak $\mathrm{Ca}_{i}$ increase versus $\mathrm{InsP}_{3}$ injection times; the linear portion could be fitted by a straight line that had a slope of $0.26 \mu \mathrm{M}$ per 100 msec injection for a pressure of $50 \mathrm{psi}$.

The InsP $\mathrm{P}_{3}$-induced increase in $\mathrm{Ca}_{i}$ occurred through release from intracellular stores. There was no noticeable change in amplitude or time course of the $\mathrm{Ca}$ signal when the bathing solution was switched to $0 \mathrm{Ca}-\mathrm{SW} . \mathrm{Ca}_{i}$ could be repeatedly mobilized by Ins $\mathrm{P}_{3}$ in cells superfused in $0 \mathrm{Ca}$-SW for more than $60 \mathrm{~min}$.

\section{Spatial variations of the InsP $P_{3}$-induced $\mathrm{Ca}^{2+}$ release}

It is known that the InsP ${ }_{3}$ released by hydrolysis of PIP ${ }_{2}$ (phosphatidylinositol 4,5-biphosphate) mobilizes $\mathrm{Ca}^{2+}$ only from some parts of the cell (Berridge and Irvine, 1989). Recent evidence has shown that $\mathrm{Ins}_{3}$-sensitive $\mathrm{Ca}$ stores are organized as discrete compartments (Berridge, 1989) that may be functionally independent (Parker and Yao, 1992). To investigate a spatial distribution of the Ins $\mathrm{P}_{3}$-sensitive stores, I made intracellular injections of $\mathrm{InsP}_{3}$ at different distances from the plasma membrane. I show in Figure 3 that the $\mathrm{Ca}_{i}$ increase seems to be spatially restricted to some areas of the cell. Figure $3 A$ shows an example where the greatest $\mathrm{Ca}$ signal, in response to identical Ins $P_{3}$ injections, occurred closer to the plasma membrane. The size of the Ca signal did not depend on the sequence in which InsP $_{3}$ injections were given. Figure $3 B$ shows the spatial profile 
of the Ca signal over a longer distance; plotted is the peak $\mathrm{Ca}_{i}$ recorded by the $\mathrm{Ca}$ electrode versus the depth of penetration. The peak Ca signal increases steeply as the electrode tip is positioned closer to the membrane. Representative $\mathrm{Ca}$ signals at four different depths are shown in the inset. The small Ca signals measured deep in the cell are not due to deterioration of the cell or clogging of the injection electrodes because injections started first deeper in the ccll and procecded toward the membrane.

A word of caution concerning the absolute depths reported in Figure 3. The zero depth was defined as the position of the electrode tip prior to its removal from the cell by a $5-15 \mu \mathrm{m}$ step. This so-called zero could be approximate because of the problem of dipping of the membrane when the microelectrode is pushcd in and out of the cell. Furthermore, Aplysia ncurons have numerous invaginations of the surface membrane (Coggeshall, 1967). However, the relative distance between any two sites (e.g., between 30 and $60 \mu \mathrm{m}$ ) should be fairly accurate.

The spatial variations of the Ca signal varied from cell to cell. The Ins $\mathrm{P}_{3}$-sensitive region was not always closest to the membrane; Figure $3 C$ shows an example of a cell where the largest Ins $\mathrm{P}_{3}$-induced $\mathrm{Ca}_{i}$ increase was located some $75 \mu \mathrm{m}$ from the inner membrane. By making reversible movements of $15 \mu \mathrm{m}$, I could repeatedly measure $I n s P_{3}$-induced $\mathrm{Ca}_{i}$ increases that were larger away from the membrane than closer to it. Figure $3 D$ shows the spatial profile for the same cell. It is evident in this $\mathrm{R} 15$ cell that the $\mathrm{Ca}_{i}$ increase, induced by identical InsP injection, gets smaller as the double-barreled Ca-selective microelectrode is approaching the membrane.

If we take $250-300 \mu \mathrm{m}$ as the average diameter of the neurons where the present measurements were made, then the histogram shown on Figure $3 E$ reveals that the largest InsP $\mathrm{P}_{3}$-induced $\mathrm{Ca}_{i}$ increases measured are contained in a region $0-80 \mu \mathrm{m}$ from the inner membrane. This may represent the area where the density of discrete compartments is larger.

\section{Summation and saturation of the Ins $P_{3}$-induced $\mathrm{Ca}_{\mathrm{i}}$ increase}

It has been reported that the action of InsP ${ }_{3}$ on the $\mathrm{Ca}^{21}$ pool is highly cooperative (Meyer et al., 1988; Berridge and Irvine, 1989) and that paired injections of Ins $_{3}$ produce facilitation (Parker and Miledi, 1989). On the other hand, in Limulus photoreceptors, the $\mathrm{Ca}_{i}$ increase inhibits the ability of $\mathrm{InsP}_{3}$ to release additional Ca from internal stores (Payne et al., 1988, 1990; Levy and Payne, 1991). To test for the mechanism of modulation in Aplysia neurons, I did multiple injections of Ins $\mathrm{P}_{3}$ separated by varying lengths of time. I found no evidence of either facilitation or negative feedback.

Figure $4 A$ shows that identical pressure injections of $\operatorname{Ins}_{3}$ evoke identical increases in $\mathrm{Ca}_{i}$ after $\mathrm{Ca}_{i}$ has returned to baseline before the next injection. In the absence of any negative feedback, the slowness of the recovery of $\mathrm{Ca}_{i}$ following injections of Ins $\mathrm{P}_{3}$ (Figs. 1-3) might suggest that multiple injections, if spaced close enough, could in fact induce summation of the Ca signal. Figure $4 B$ shows indeed that successive $\mathrm{Ca}$ signals summate when evoked by successive Ins $\mathrm{P}_{3}$ injections. The level of $\mathrm{Ca}_{i}$ during a train of injections usually reached a plateau after the fourth or fifth injection, no matter how long the train was.

The level of $\mathrm{Ca}_{i}$ reached was usually maximal in a given cell when the injection of InsP $\mathrm{P}_{3}$ was continuous. Figure $4 C$ shows superimposed $\mathrm{Ca}$ signals induced by injections of increasing amounts of InsP $_{3}$ in the same cell as Figure $4 B$. The injections $\left(100 \mu \mathrm{M} \operatorname{InsP}_{3}, 70 \mathrm{psi}\right)$ lasted 26 and $80 \mathrm{sec}$, respectively; the
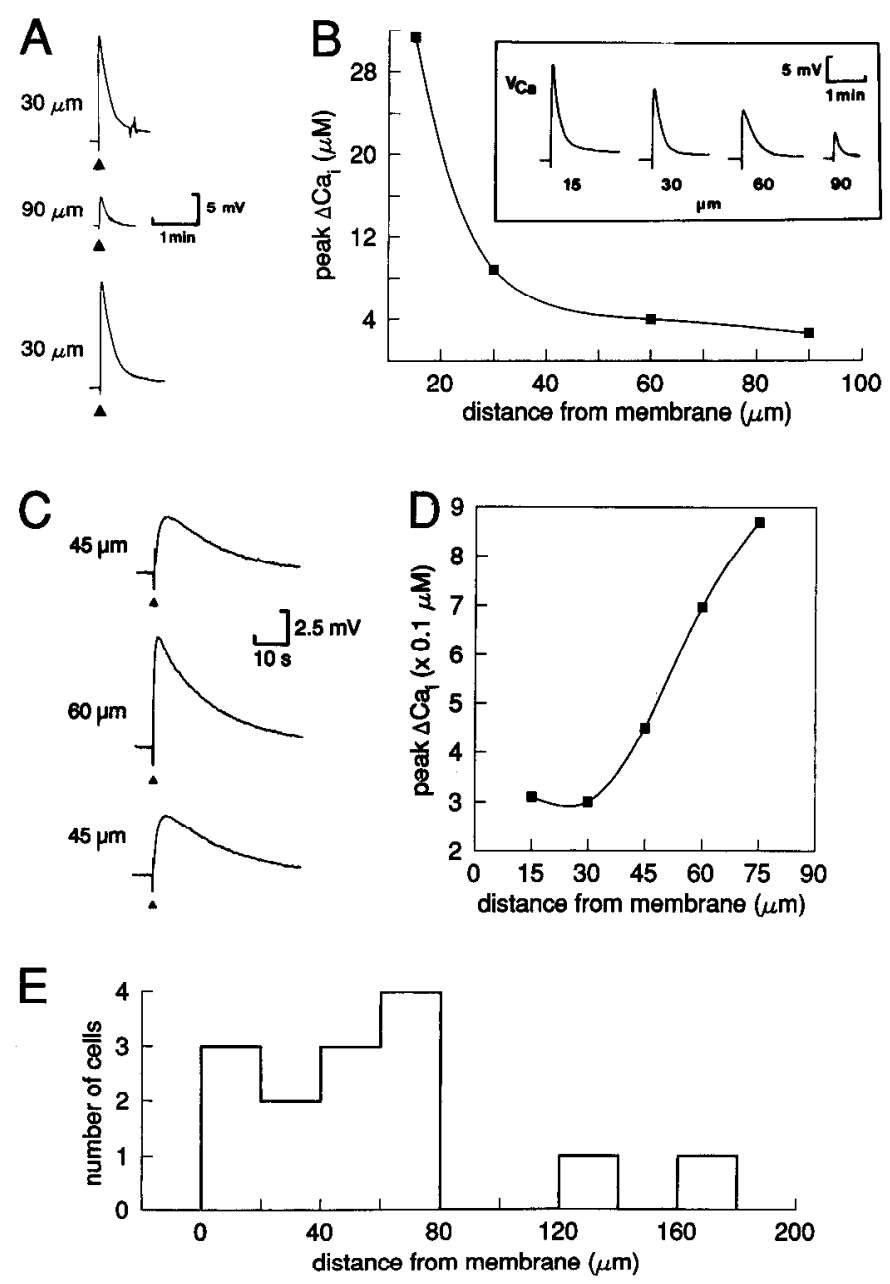

Figure 3. Spatial variation of the $\operatorname{Ins}_{3}$-induced $\mathrm{Ca}_{i}$ increase: examples of greatest $\mathrm{Ca}^{2+}$ release near the membrane $(A, B)$ or away from it $(C$, $D$ ). In both $A$ and $C$, arrowheads indicate injection of Ins $\mathrm{P}_{3}$; the numbers on the left indicate approximate depths in relation to zero position. $A$ : Top trace, Ca signal in response to a brief injection. Moving the electrode in by $60 \mu \mathrm{m}$ resulted in a much smaller Ca signal (middle trace). Movement of the electrode back to its original position restored the original Ca signal (bottom trace). $B$, Plot of Ins $P_{3}$-induced $\mathrm{Ca}_{i}$ increase versus the depth of the injecting electrode. The double-barreled electrode was first inserted deeply into a neuron; it was then withdrawn in steps of 15 $\mu \mathrm{m}$, with its tip approaching the membrane surface. Following each change in depth, Ins $\mathrm{P}_{3}$ was pressure injected and $\mathrm{Ca}_{i}$ measured. Representative records at four different depths are shown in the inset. The measured amplitude of the $\mathrm{Ca}$ electrode potential, induced by a standard InsP $\mathrm{P}_{3}$ injection (10 $\mu \mathrm{M}$-filled electrode, $30 \mathrm{psi}, 400 \mathrm{msec}$ ), increases steeply as the electrode tip is positioned closer to the membrane surface. See text for zero depth definition. C:Top trace, Ca signal in response to a brief injection. Advancing the electrode by $15 \mu \mathrm{m}$ resulted in a larger Ca signal (middle trace). Withdrawing of the electrode by $15 \mu \mathrm{m}$ restored the original Ca signal (bottom trace). $D$, Plot of InsP $\mathrm{P}_{3}$-induced $\mathrm{Ca}_{i}$ increase versus the depth of the injecting electrode (same protocol as $B$ ). This time, the measured amplitude of the $\mathrm{Ca}$ electrode potential, induced by a standard Ins $\mathrm{P}_{3}$ injection (100 $\mu \mathrm{M}$-filled electrode, $40 \mathrm{psi}, 20$ $\mathrm{msec}$ ), decreases as the electrode tip is positioned closer to the membrane surface. $E$, The histogram shows the distribution of the largest InsP ${ }_{3}$ induced $\mathrm{Ca}_{i}$ increase in several nerve cells.

rise time and decay to baseline of both Ca signals were nearly identical; the effect of the larger injection was simply to lengthen the duration of the $\mathrm{Ca}$ signal increase. The $\mathrm{Ca}$ signal reached a plateau, meaning that a steady state seemed to be reached between the rate of $\mathrm{Ca}^{2+}$ release and the rate of buffering. 

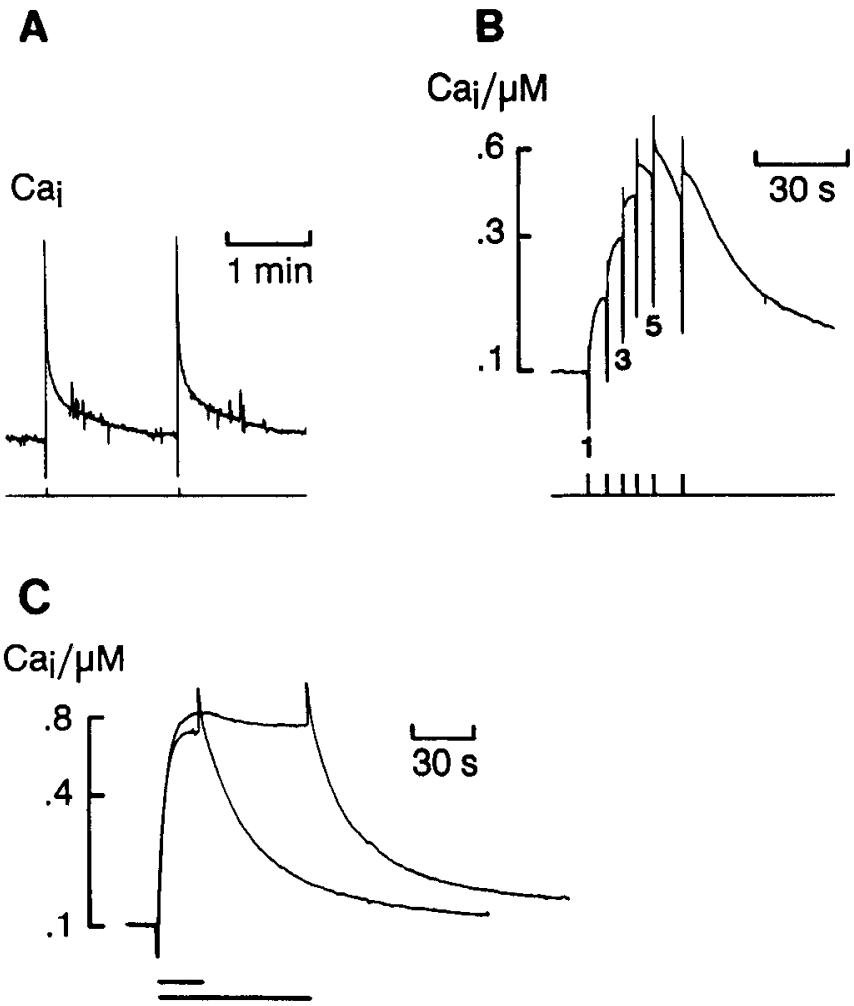

Figure 4. Summation and saturation of the $\mathrm{InsP}_{3}$-induced $\mathrm{Ca}_{i}$ increase. $A$, Lack of facilitation and feedback inhibition as evidenced by identical $\mathrm{Ca}_{i}$ increases induced by identical, successive Ins $\mathrm{P}_{3}$ injections. The $\mathrm{Ca}_{i}$ increase was $1.4 \mu \mathrm{M}$ at the peak of both transients. The time of the injections ( $50 \mathrm{psi}, 400 \mathrm{msec}, 1 \mathrm{~mm} \mathrm{InsP_{3 }}$ ) is shown in the lower trace. The small potential changes during the $\mathrm{Ca}_{i}$ recovery are electrical artifacts due to inadequate spatial control of the membrane potential. R15 cell; depth, $90 \mu \mathrm{m}$. $B, \mathrm{Ca}_{i}$ changes induced by multiple, identical pressure injections of Ins $\mathrm{P}_{3}(100 \mu \mathrm{M}$ solution). The lower trace shows the timing of the pulses (500 msec each, 70 psi). Injections 1-3 were presented after $\mathrm{Ca}_{i}$ reached a plateau and before it started recovering; under these conditions the $\mathrm{Ca}$ signals summate and the total peak $\mathrm{Ca}_{i}$ increases. Hardly any additional $\mathrm{Ca}_{i}$ increase is seen after injection 4 . The negativegoing potentials are injection artifacts (see Fig. $1 B$ ). $C$, Saturation of the $\mathrm{Ca}_{i}$ increase by pressure injection of increasing amounts of $\mathrm{InsP}_{3}(100$ $\mu \mathrm{M}$ solution). The Ca signals resulting from injections of different durations (as marked by bars below the traces) were superimposed. The injections lasted 26 and $80 \mathrm{sec}(70 \mathrm{psi})$; the rise time and decay to baseline of both $\mathrm{Ca}$ signals were nearly identical; the effect of the larger injection was simply to lengthen the duration of the $\mathrm{Ca}$ signal increase. Both $B$ and $C$ : cell $\mathrm{R} 2$, depth $30 \mu \mathrm{m}$. The maximum increase in this cell was reached during the continuous $\operatorname{Ins}_{3}$ injection and not during successive, multiple brief injections.

I checked whether interfering with the inositol phosphate metabolism by using lithium would modify the $\operatorname{InsP}_{3}$-induced $\mathrm{Ca}_{i}$ increase. Lithium has been shown to inhibit the breakdown of InsP $P_{1}$ by inhibiting Ins $P_{1}$ phosphatase. When I superfused nerve cells with $\mathrm{Li}^{+}$(45 mM, substituted for $\mathrm{Na}^{+}$), I saw no difference in the amplitude or waveform of the InsP $\mathrm{P}_{3}$-induced $\mathrm{Ca}_{i}$ increase (two experiments).

\section{Injection of other inositol polyphosphates}

I checked the specificity of the Ca-mobilizing effect of Ins $(1,4,5) \mathrm{P}_{3}$ by injecting related compounds. It was reported that $\operatorname{Ins}(2,4,5) \mathrm{P}_{3}$ is an efficient $\mathrm{Ca}$ mobilizer with a potency that is less than Ins $(1,4,5) \mathrm{P}_{3}$ (Irvine and Moor, 1986). What makes Ins $(2,4,5) \mathrm{P}_{3}$ an interesting compound is that, unlike $\operatorname{Ins}(1,4,5) \mathrm{P}_{3}$, it cannot be phosphorylated to $\operatorname{Ins}(1,3,4,5) \mathrm{P}_{4}$, which supposedly promotes $\mathrm{Ca}^{2+}$ entry (Berridge and Irvine, 1989). I found that both $\operatorname{Ins}(2,4,5) \mathrm{P}_{3}$ and $\operatorname{Ins}(1,3,4,5) \mathrm{P}_{4}$ were able to mobilize $\mathrm{Ca}^{2+}$, but in general the amounts injected had to be increased in order to see increases in $\mathrm{Ca}_{i}$ comparable to those mobilized by Ins $(1,4,5) \mathrm{P}_{3}$. I also found that both inositol polyphosphates were able to mobilize $\mathrm{Ca}^{2+}$ in $0 \mathrm{Ca}-\mathrm{SW}$.

\section{Effect of InsP $P_{3}$ injections on bursting activity}

The pacemaker cycle of Aplysia bursting neurons has two membrane conductance systems both dependent on changes in $\mathrm{Ca}_{i}$ (Gorman et al., 1981; Adams, 1985; Kramer and Zucker, $1985 a, b)$. Moreover, the bursting can be modulated by several neurotransmitters (Levitan et al., 1979; Smith, 1980). It is possible that some agonists modulate membrane conductances by releasing $\mathrm{InsP}_{3}$. To test the hypothesis that changes in membrane properties could be directly modulated by $\operatorname{Ins}_{3}$ (or indirectly through $\mathrm{Ca}^{2+}$ mobilization), I injected $\operatorname{InsP}_{3}$ and measured changes in membrane potential or total membrane current. Figure 5 shows that injection of InsP $P_{3}$ had a marked effect on the bursting frequency and the membrane potential of an R15 pacemaker neuron. Injection of $1 \mathrm{mM} \mathrm{InsP}_{3}$ induced an immediate train of action potentials (arrowheads 1-3) followed by membrane hyperpolarization. After the cell recovered from the hyperpolarization, the burst frequency had noticeably decreased. Both the Ins $\mathrm{P}_{3}$-induced immediate discharge of action potentials and the hyperpolarization depended on the amount of $\operatorname{InsP}_{3}$ injected. Large injections (arrowhead 3) increased the duration of the interburst hyperpolarization without increasing further its amplitude. Additional injections during the prolonged hyperpolarization caused the cell to fire action potentials (not shown).

\section{Effect of Ins $P_{3}$ injection on total membrane currents}

To gain insight into the mechanism of action of $\operatorname{Ins}_{3}$ on the bursting activity, I injected Ins $\mathrm{P}_{3}$ in voltage-clamped cells and monitored the total membrane current. Conventional, singlebarreled micropipettes filled with Ins $\mathrm{P}_{3}$ were used for these experiments. Figure $6 A$ shows that injection of $\operatorname{InsP}_{3}$ in an $\mathrm{R} 15$ cell resulted in a biphasic response: a relatively rapid inward current followed by a more prolonged outward current. I also found that the relative magnitude of the inward and outward current changed with depth within the cell. Figure $6 B$ shows a plot of peak inward and outward current versus the depth of the injecting electrode; the peak inward current increased linearly as the injection electrode approached the inner membrane. The outward current remained small until the injecting electrode approached the membrane. Scholz et al. (1988) described a similar biphasic response caused by InsP $_{3}$ injections in Aplysia. Sawada et al. (1987) found only outward currents in Aplysia kurodai neurons. The biphasic response shown in Figure $6 \mathrm{~A}$ resembles the response caused by $\mathrm{Ca}^{2+}$ injections in Helix neurons (Hofmeier and Lux, 1981) and could be the $\mathrm{Ca}^{2+}$-dependent, nonspecific cation current responsible for maintaining repetitive spiking during the burst of Helix (Swandulla and Lux, 1985) and Aplysia (Kramer and Zucker, 1985a,b) neurons.

For control injections, I used double-barreled injecting microelectrodes, where one barrel was filled with myo-inositol and the other barrel with $\operatorname{lns}_{3}$. Figure $6 C$ shows that control injections of $1 \mathrm{~mm}$ myo-inositol at depths of $50 \mu \mathrm{m}$ (left panel) and $30 \mu \mathrm{m}$ (right panel) did not produce any apprcciable changc in total membrane current. Injections of $\operatorname{Ins}_{3}$ at the same site 


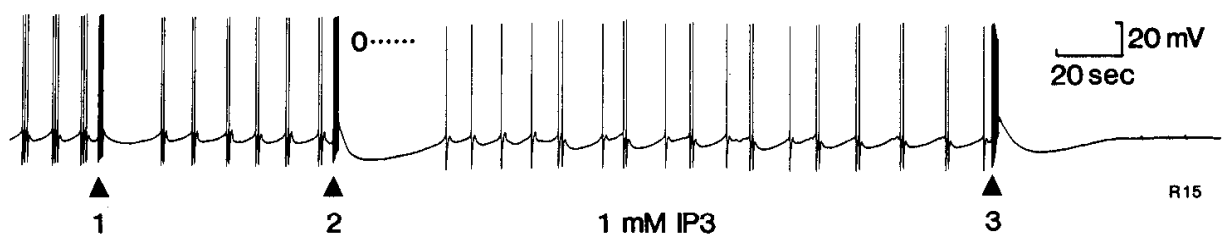

Figure 5. Effect of InsP $\mathrm{P}_{3}$ injections on bursting frequency and membrane potential of an $\mathrm{R} 15$ Aplysia neuron. The cell was impaled with a voltage electrode and a single micropipette filled with $1 \mathrm{~mm} \mathrm{Ins} \mathrm{P}_{3}$. The 0 potential is shown by a dotted line. Each injection (30 psi) is indicated by an arrowhead. Arrowheads 1, 2, and 3 correspond to $200 \mathrm{msec}, 400 \mathrm{msec}$, and $600 \mathrm{msec}$ long injections, respectively. Each injection increases the frequency of the action potentials (because of the slow time scale, these are seen as a thick vertical line following the injection). The increased frequency is followed by a hyperpolarization whose duration seems to depend on the amount of Ins $\mathrm{P}_{3}$ injected.

induced large changes in membrane current. It is important to do the control injections at the same site since the membrane current changes are highly depth dependent.

\section{Differential effects of $\mathrm{Ca}^{2+}$ and InsP $P_{3}$ injections on membrane currents}

To find out whether the effect of Ins $P_{3}$ on membrane currents is primary or mediated by the $\mathrm{Ca}^{2+}$ released by $\mathrm{InsP}_{3}$, I intracellularly injected $\mathrm{Ca}^{2+}$ and $\mathrm{Ins} \mathrm{P}_{3}$ at the same sitc. I uscd doublcbarreled injecting microelectrodes filled with $10 \mathrm{mM} \mathrm{Ca}^{2+}$ and

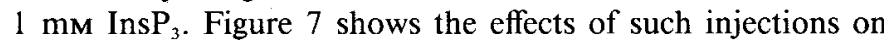
membrane currents in two types of neurons, R15 and L3. The depth of the injecting electrode is given in the Figure 7 caption. Membrane currents induced by $\mathrm{Ca}^{2+}$ or $\operatorname{Ins} \mathrm{P}_{3}$ injections differed in waveform and time course. Ca injections typically induced outward currents, while InsP $_{3}$ injections induced inward currents. Similar results were found in a total of 12 cells from 12 different ganglia. To test directly the hypothesis that $\operatorname{InsP}_{3}$ activates membrane currents that seem to be independent of the
$\mathrm{Ca}_{i}$ increase, InsP $\mathrm{P}_{3}$ and $\mathrm{Ca}$ were injected side by side in the presence of BAPTA. BAPTA was chosen over EGTA, because it is a much faster $\mathrm{Ca}$ buffer; for example, certain $\mathrm{Ca}$-mediated effects were found to be resistant to EGTA, but not to BAPTA (Adler et al., 1991; Frank and Fein, 1991). Figure 8 shows that in the presence of BAPTA, the Ca-induced outward current was substantially reduced while the InsP $_{3}$-induced inward current was largely unaffected. The Ins $\mathrm{P}_{3}$-induced current changes were resistant to BAPT $\Lambda$ in three more cells. In three other cells, BAPTA effectively chelated intracellular $\mathrm{Ca}^{2+}$, since the $\mathrm{Ca}$ dependent slow tail currents, induced by depolarization, were greatly reduced. These results suggest that the current changes induced by Ins $\mathrm{P}_{3}$ injections may be primary and are not explained solely by a $\mathrm{Ca}_{i}$ increase.

\section{Simultaneous measurement of membrane current and $C a_{\mathrm{i}}$ induced by $\operatorname{InsP}_{3}$ injections}

The fact that the membrane conductance changes are different for $\mathrm{Ca}^{2+}$ and $\mathrm{InsP}_{3}$ injections does not exclude that the mem-
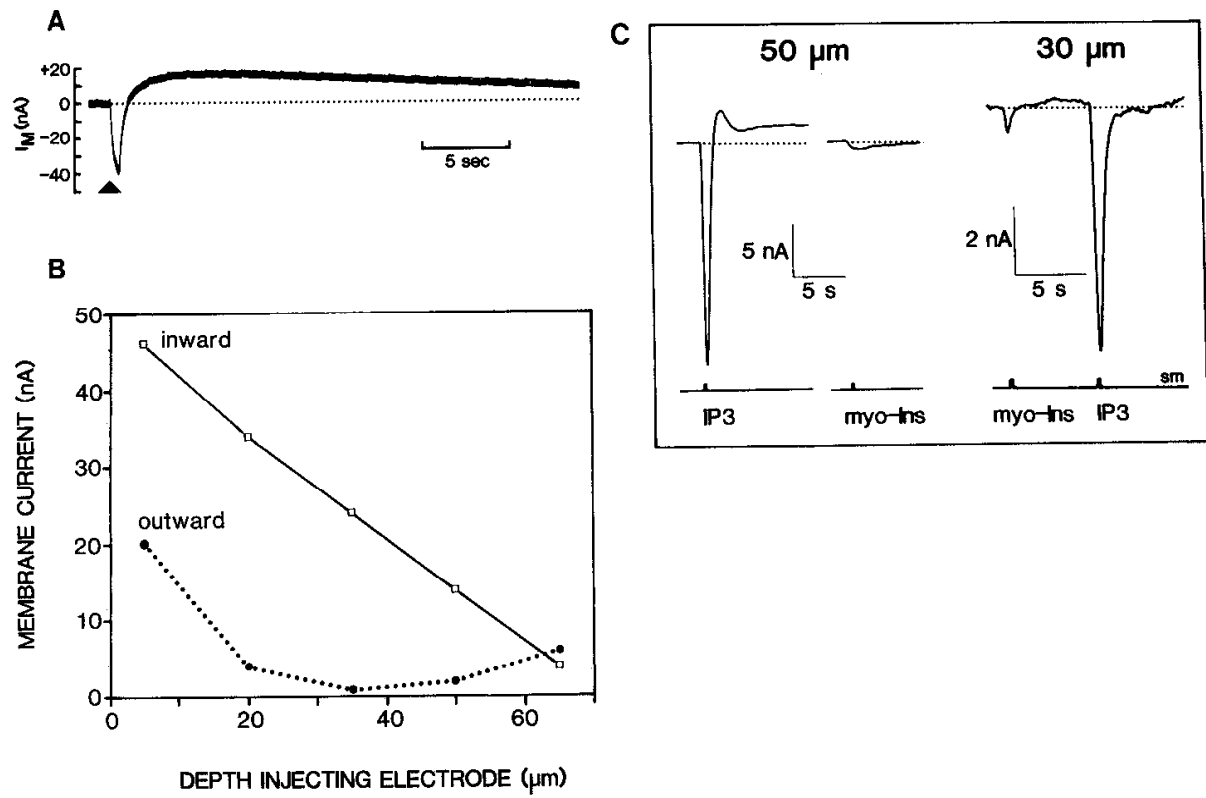

Figure 6. Effect of intraccllular $\operatorname{Ins}_{3}$ injection on membrane current of an $\mathrm{R} 15$ cell. The cell was voltage clamped at $-45 \mathrm{mV}$ and the total membrane current measured as illustrated in Figure $1 A$, except that the double-barreled microelectrode was replaced by a single-barreled injection electrode. $A$, Pressure injection of InsP $_{3}(275 \mu \mathrm{M}$ solution, $50 \mathrm{psi}, 200 \mathrm{msec})$ results in a biphasic response that consists of a rapidly developing inward current followed by a more prolonged outward current. $B$. Plot of the peak inward and outward currents induced by single injections of Ins $\mathrm{P}_{3}$ versus the depth of the injecting electrode; the peak inward current increased linearly as the injection electrode approached the inner membrane, while the outward current did not start increasing until the injecting electrode approached the inner membrane. $C$, Injection of 1 mM $m y o$-inositol at depths of $50 \mu \mathrm{m}$ (left) and $30 \mu \mathrm{m}$ (right) did not result in any noticeable increase in membrane current, whereas injection of $1 \mathrm{~mm}$ Ins $\mathrm{P}_{3}$ at the same sites had a marked effect. Both compounds were injected using a double-barreled injecting electrode. 

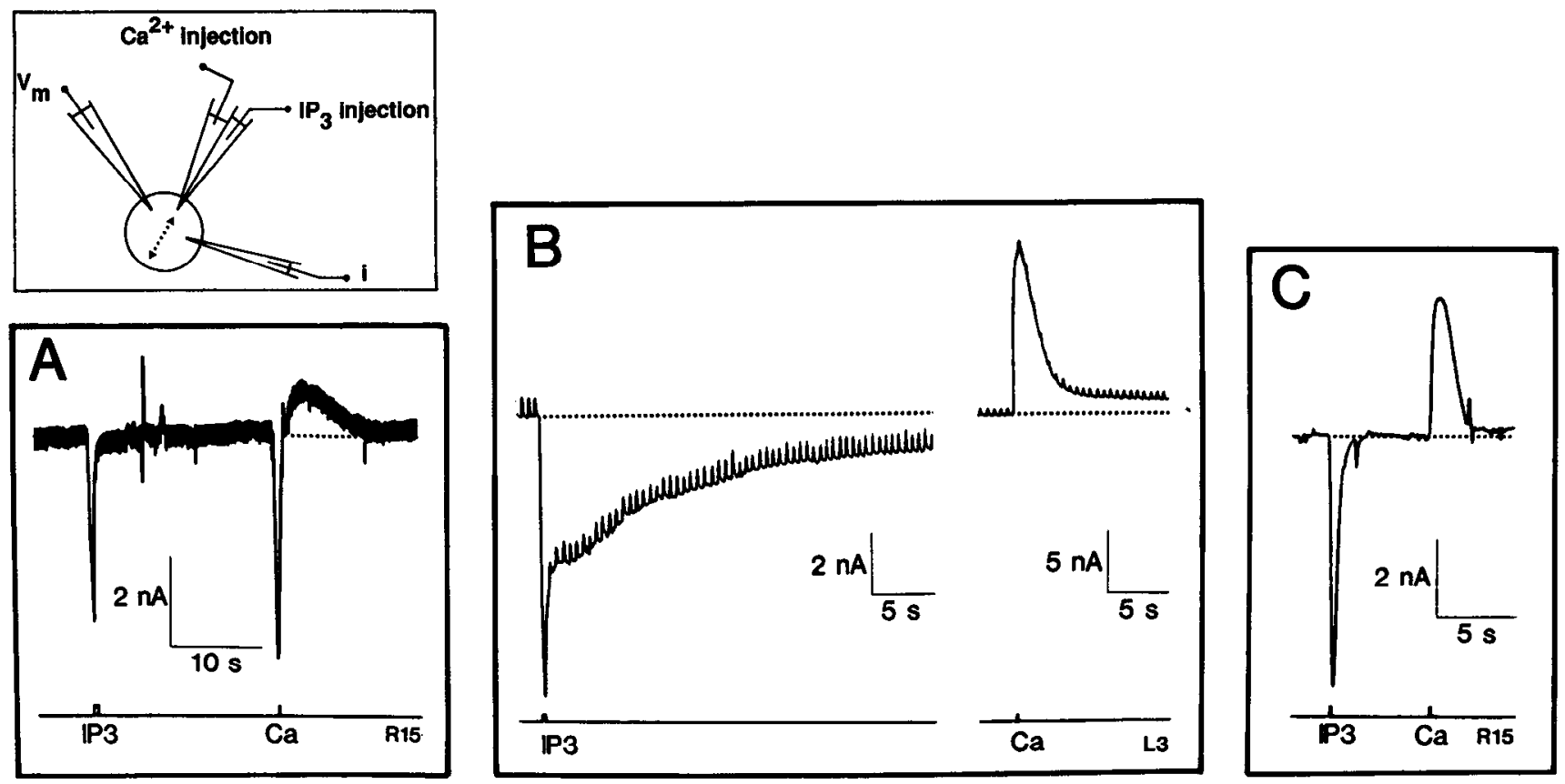

Figure 7. Effect of injecting $\mathrm{Ca}^{2+}$ and InsP $\mathrm{P}_{3}$ at the same site on membrane currents. Inset, Experimental arrangement showing the double-barreled injecting electrode that allows delivery of either $\mathrm{Ca}^{2+}\left(10 \mathrm{~mm}\right.$ solution) or InsP $\mathrm{P}_{3}(1 \mathrm{~mm})$ solution at the same point. Cells: $A, C, \mathrm{R} 15 ; B, \mathrm{~L} 3$. Depth of the injecting electrodes: $A, 60 \mu \mathrm{m} ; B, 40 \mu \mathrm{m} ; C, 25 \mu \mathrm{m}$.

brane current and the $\mathrm{Ca}^{2+}$ mobilized by $\mathrm{Ins}_{3}$ may be related. One way to find out is to follow changes in membrane current and $\mathrm{Ca}_{i}$ simultaneously in response to $\mathrm{InsP}_{3}$ injections. Figure $9 A$ shows such changes in an R15 cell. In the inset of Figure $9 A$, the recorded Ca signal (voltage) was converted to a linear ion concentration scale to facilitate comparison with the inverted and normalized membrane current trace. The inset shows that although the current and the $\mathrm{Ca}_{i}$ trace start rising simul-

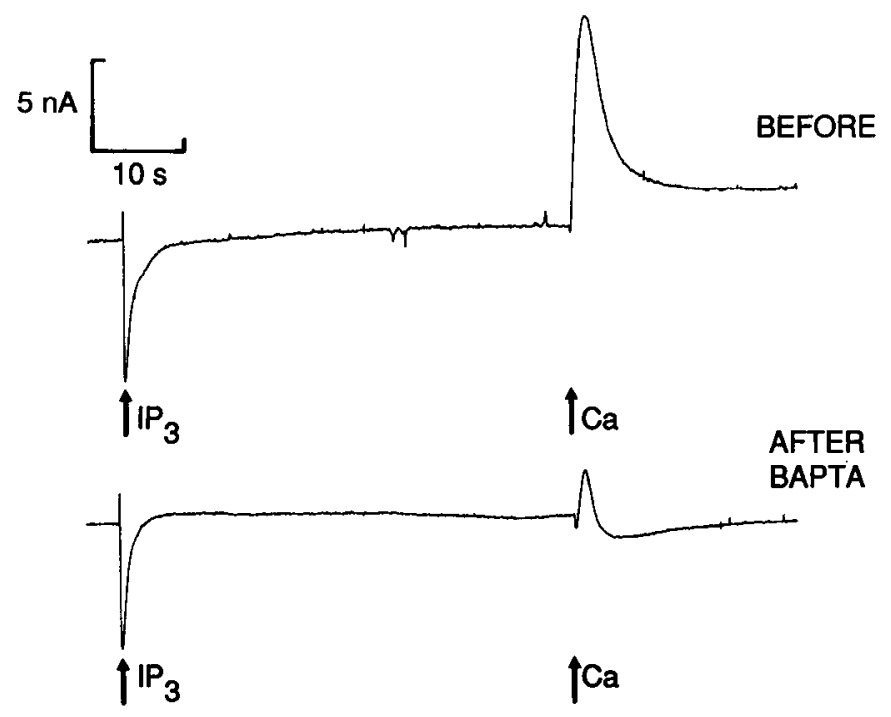

Figure 8. The Ins $\mathrm{P}_{3}$-induced membrane current change subsists in BAPTA-loaded cells. Side-by-side injection of $\mathrm{InsP}_{3}$ and $\mathrm{Ca}^{2+}$ before (upper trace) and after pressure injection of BAPTA (15 injections, 60 psi, $200 \mathrm{msec}$ each). The increased Ca buffering capacity was effective in reducing the Ca-induced outward current, but not the Ins $\mathrm{P}_{3}$-induced inward current (same experimental arrangement as the inset of Fig. 7 , except that the $V_{m}$ electrode was filled with 100 mM BAPTA). taneously, the $\mathrm{InsP}_{3}$-induced membrane current recovers faster than the Ca signal. The same is true for the $\mathrm{Cl}^{-}$current and the Ca signal changes induced by Ins $\mathrm{P}_{3}$ in oocytes (Parker and Ivor$\mathrm{ra}, 1990 \mathrm{a})$. The inset of Figure $9 A$ also shows that the peak $\mathrm{Ca}_{i}$ increase is delayed in relation to the peak membrane current, which is probably the result of the relative slowness of the Caselective microelectrode; the true $\mathrm{Ca}_{i}$ peak is probably larger and faster.

Another way to assess whether the Ca signal and the membrane current are related is by looking at their relative spatial variation following $\mathrm{Ins}_{3}$ injections. Figure $9 B$ shows a plot of peak $\mathrm{Ca}_{i}$ increase and peak inward current versus the depth of the Ins $\mathrm{P}_{3}$-injecting double-barreled $\mathrm{Ca}$ electrode. Both peaks changed relatively by the same amount as the injecting electrode approached the surface membrane. So, although side-by-side $\mathrm{Ca}^{2+}$ and $\mathrm{InsP}_{3}$ injections induce different current waveforms, it looks as though the $\mathrm{InsP}_{3}$-induced membrane current changes may be spatially related to the mobilized $\mathrm{Ca}^{2+}$. Further experiments will be necessary to separate the effects of $\mathrm{Ca}^{2+}$ and InsP on membrane currents in molluscan neurons.

\section{Discussion}

The results suggest that intracellular injections of Ins $\mathrm{P}_{3}$ in identified nerve cells of Aplysia californica mobilize $\mathrm{Ca}^{2+}$ from intracellular stores and also induce distinct changes in membrane currents that seem to be independent of the $\mathrm{Ca}_{i}$ increase.

In previous studies, the effect of Ins $\mathrm{P}_{3}$ in nerve cells of Aplysia kurodai (Sawada et al., 1987) and Aplysia californica (Sholz et al., 1988) was indirectly shown to mobilize $\mathrm{Ca}^{2+}$, by measuring membrane currents. Fink et al. (1988) have shown, using digital imaging of fura-2 fluorescence, that InsP $\mathrm{P}_{3}$ increases $\mathrm{Ca}_{i}$ in Aplysia bag cells. In this study, I directly measured InsP $_{3}$-induced $\mathrm{Ca}_{i}$ increases using double-barreled Ca-selective microelectrodes. I found that the Ins $\mathrm{P}_{3}$-induced $\mathrm{Ca}_{i}$ increase was graded with the amount of $\mathrm{InsP}_{3}$ injected. A similar dose-response 
A

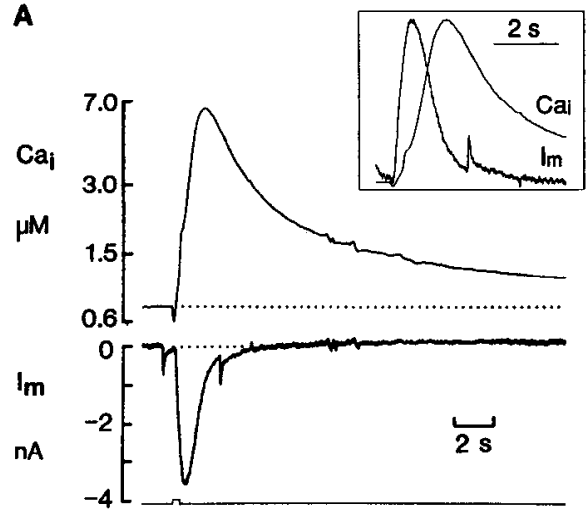

B

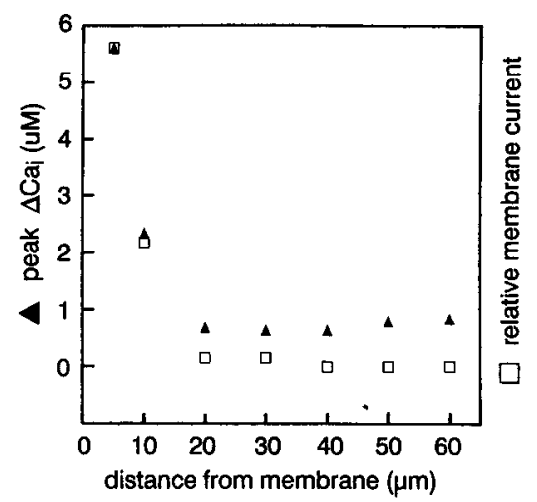

Figure 9. Temporal relations of membrane current and $\mathrm{Ca}_{i}$ measured simultaneously. $A$, Comparison of the time course of membrane current (middle trace) and measured Ca signal (top trace) induced by intracellular injection of Ins $\mathrm{P}_{3}$ in an $\mathrm{R} 15$ cell. Note how the membrane current recovers a few seconds following the injection whereas the Ca signal increase is still relatively high; it took about 80 sec for the Ca signal to reach the baseline (not shown). In the inset, the current trace was inverted and normalized to the Ca signal trace to show the shift in peak amplitude in relation to the $\mathrm{Ca}$ signal; the $\mathrm{Ca}$ signal was converted from voltage (which varies with the log of the $\mathrm{Ca}^{2+}$ concentration) to a linear $\mathrm{Ca}{ }^{2+}$ concentration scale. Both traces in the inset were sampled at $0.5 \mathrm{kHz}$ and digitized. The double-barreled Ca-selective microelectrode was about $5 \mu \mathrm{m}$ from the membrane surface. Injection: $50 \mathrm{psi}, 400 \mathrm{msec}, 1 \mathrm{~mm}$ InsP $\mathrm{P}_{3}$ solution. $B$, Spatial variations of the $\mathrm{Ca}_{i}$ increase and membrane current induced by Ins $\mathrm{P}_{3}$ injection. Plotted are the peak $\mathrm{Ca}_{i}$ increase and membrane current versus the depth of the double-barreled microelectrode; the peak current was normalized to the peak of the largest $\mathrm{Ca}_{i}$ increase $\left(5 \mu \mathrm{m}\right.$ point). Same protocol as Figure $3 B$. R15 cell, $50 \mathrm{psi}, 400 \mathrm{msec}$ injections, $1 \mathrm{~mm}$ InsP $\mathrm{P}_{3}$ solution.

relationship was found in other preparations using fura-2 fluorescence (Meyer et al., 1988) or ${ }^{45} \mathrm{Ca}$ (Gawler et al., 1990; Finch et al., 1991). Our results also agree with those of Sawada et al. (1987) for the InsP $\mathrm{P}_{3}$-activated outward current, and those of Parker and Ivorra (1990b) for chloride currents and $\mathrm{Ca}_{i}$ increases.

The intracellular Ca store has supposedly a limited capacity to release $\mathrm{Ca}^{2+}$ and thus to sustain a $\mathrm{Ca}_{i}$ increase, other mechanisms must exist, notably $\mathrm{Ca}$ influx (Michell, 1975; Putney, 1986; Berridge and Irvine, 1989; Takemura and Putney, 1989). Matthews et al. (1989) found evidence for $\mathrm{InsP}_{3}$-induced Ca influx in mast cells. In this study, I was able to induce $\mathrm{Ca}^{2+}$ increases by $\mathrm{InsP}_{3}$ injections in $0 \mathrm{Ca}-\mathrm{SW}$ repeatedly for up to 60 min. This may mean that Aplysia nerve cells have unusually large stores of $\mathrm{Ca}^{2+}$ or that the released $\mathrm{Ca}^{2+}$ is returned to the Ins $\mathrm{P}_{3}$-sensitive store efficiently.

A complex aspect of the $\mathrm{InsP}_{3}$ signaling system is the way the Ins $\mathrm{P}_{3}$-induced $\mathrm{Ca}_{i}$ increase is modulated. In many cell types, $\mathrm{Ca}^{2+}$ ions inhibit the action of $\mathrm{InsP}_{3}$ to induce further mobilization of $\mathrm{Ca}^{2+}$ from intracellular stores (Payne et al., 1988, 1990; Berridge, 1989; Parker and Ivorra, 1990a). This feedback inhibition is preceded in some preparations by facilitation, whereby a prior elevation of $\mathrm{Ca}^{2+}$ potentiates the effect of $\operatorname{InsP}_{3}(\mathrm{Sa}-$ wada et al., 1987; Parker and Ivorra, 1990a; Finch et al., 1991). The feedback inhibition was recently shown to be mediated by the lingering elevation of $\mathrm{Ca}_{i}$ that follows mobilization of $\mathrm{Ca}^{2+}$ by $\mathrm{InsP}_{3}$ (Levy and Payne, 1991; Payne, 1991). The results of Figure $4 B$ show that the initial elevation of $\mathrm{Ca}_{i}$ does not inhibit subsequent increases of $\mathrm{Ca}_{i}$ by $\operatorname{Ins}_{3}$. Desensitization occurred only after several injections have elevated $\mathrm{Ca}_{i}$ further. One possibility is that different preparations have different thresholds of elevated $\mathrm{Ca}_{i}$ to produce desensitization.

The mobilization of $\mathrm{Ca}^{2+}$ by $\mathrm{InsP}_{3}$ has been shown in many systems to be spatially restricted to some areas of the cells (Levy, 1987; Payne and Fein, 1987; Parker and Ivorra, 1990b). Berridge (1989) found that the $\mathrm{InsP}_{3}$-induced $\mathrm{Cl}^{-}$current desensitization in Xenopus oocytes was restricted to the point of injection and proposed that the $\mathrm{InsP}_{3}$-sensitive pool is composed of discrete compartments, a concept supported by recent evidence (Parker and Yao, 1992). The results presented on Figure 3 show strong evidence that the Ins $\mathrm{P}_{3}$-induced $\mathrm{Ca}_{i}$ increase is nonuniform in Aplysia nerve cells. Regarding our own experimental design, which required moving the double-barreled $\mathrm{Ca}$ microelectrodes and injecting at different points, could the apparent spatial localization be the result of some artifact like reversible electrode clogging or limited dissipation of injected $\mathrm{InsP}_{3}$ ? Electrode clogging cannot explain differences that can be measured in both directions of penetration depending on where the site of highest InsP $P_{3}$-induced $\mathrm{Ca}_{i}$ increase is located. Also I can reversibly induce different magnitudes of $\mathrm{InsP}_{3}$-induced $\mathrm{Ca}_{i}$ increase simply by moving the injection electrode back and forth (Fig. $3 A, C$ ). In my own hands, I have always seen injection electrodes getting clogged irreversibly. Regarding possible limitations to the diffusion of InsP ${ }_{3}$, it could be argued that as the injection electrode approaches the plasma membrane, the diffusion of the injected Ins $\mathrm{P}_{3}$ is more restricted due to the presence of the membrane, and this could explain a larger mobilized $\mathrm{Ca}^{2+}$ concentration at that point. The results of Figure 3, $C$ and $E$, argue against restricted diffusion as the cause of spatial differences in $\mathrm{Ins}_{3}$-induced $\mathrm{Ca}_{i}$ increase that $\mathrm{I}$ measure, since the largest Ins $\mathrm{P}_{3}$-induced $\mathrm{Ca}_{i}$ increase was found in some cells to be some 80-120 $\mu \mathrm{m}$ away from the membrane. It is of interest to mention that the Ca buffering capacity in Aplysia nerve cells is largest near the plasma membrane (Tillotson and Gorman, 1980), so it is possible that the largest $\mathrm{InsP}_{3}$-induced $\mathrm{Ca}_{i}$ increase seen near the plasma membrane would have been larger if not for the increased $\mathrm{Ca}$ buffering capacity. I conclude that the spatial difference in ability for a given injection of $\mathrm{InsP}_{3}$ to mobilize $\mathrm{Ca}^{2+}$ reflects a real difference in localization of the internal stores of $\mathrm{Ca}$.

If we support the concept of separate local compartments (Berridge, 1989; Parker and Yao, 1992), the differences in Ca signals that I measure could be due to the proximity of the injection electrode to a more or less dense population of compartments. Further support to the concept of discrete compartments may come from an interesting result from the inset of 
Figure $3 B$ : regardless of the size of the Ca signal, the time to peak of the Ins $\mathrm{P}_{3}$-induced $\mathrm{Ca}_{i}$ increase seems to be the same. This may mean that the injected InsP $_{3}$ is reaching $\mathrm{Ca}$ stores at each depth, only the difference in the number of compartments makes it that larger responses are obtained when more sites are simultaneously activated by $\operatorname{Ins}_{3}$. A similar time to peak of the Ca signal at depths of 30 and $90 \mu \mathrm{m}$ (Fig. 3A) is unlikely to be due to some distortion by the dynamic response of the $\mathrm{Ca}$ electrode. If the small Ca signal at $90 \mu \mathrm{m}$ was the result of $\mathrm{Ca}^{2+}$ diffusing from a site near the plasma membrane, its time to peak would have been much larger, as demonstrated before in similar conditions (Levy and Fein, 1985). The significance of this highly localized distribution of Ins $\mathrm{P}_{3}$-sensitive Ca stores is unclear. One possibility is that $\mathrm{Ca}^{2+}$ is mobilized by $\mathrm{InsP}_{3}$ where it is most effective. For example, in Limulus photoreceptors, phototransduction is rapid and efficient because of the close proximity of the visual pigment rhodopsin, the sites of release of InsP $\mathrm{P}_{3}$, the Ins $\mathrm{P}_{3}$-sensitive $\mathrm{Ca}$ stores, and the $\mathrm{Ca}$-sensitive receptors (Payne and Fein, 1987). A consideration in the case of Aplysia nerve cells, where $\mathrm{Ca}$ influx is substantial, is that it may be important to segregate entering and mobilized $\mathrm{Ca}^{2+}$ ions because they may have different target molecules. Alternatively, $\mathrm{Ca}$ influx could be more or less potentiated through mobilized $\mathrm{Ca}$, by reaching a different number of discrete compartments.

An interesting aspect of molluscan pacemaker potentials is that they can be altered by neurohormones like vasopressin or egg-laying hormone (Levitan et al., 1979; Smith, 1980). These neurohormones could act through $\mathrm{G}$-protein activation of phospholipase C. In accordance with previous findings (Scholz et al., 1988 ), my data suggest that Ins $\mathrm{P}_{3}$ could play a role in modulating the bursting activity of Aplysia pacemaker neurons. InsP $\mathrm{P}_{3}$ injection into bursting R15 neurons causes an immediate train of action potentials followed by membrane hyperpolarization and later by a decrease in burst frequency (Fig. 5). It is not clear whether the initial membrane hyperpolarization is due to a direct effect of $\mathrm{InsP}_{3}$ or to an increased entry of $\mathrm{Ca}^{2+}$ following the train of action potentials. Thomas and Gorman (1977) have shown that increased $\mathrm{Ca}^{2+}$ entry (by passing current during a burst) does result in a larger hyperpolarization, but under this condition it is not followed by a decrease in interburst frequency. One has to keep in mind that a neurotransmitter would release both InsP $\mathrm{P}_{3}$ and diacylglycerol. The effect of the latter on bursting is not known. Strong et al. (1987) have shown that activation of protein kinase $\mathrm{C}$ in Aplysia bag cells leads to enhancement of Ca currents. In preliminary experiments, we found that $A p l y$ sia neurons from the abdominal ganglion (devoid of bag cells) contain all the endogenous inositol phosphates and lipids (S. Levy and E. Szuts, unpublished observations).

The presence of the Ca-mobilizing effect of $\operatorname{InsP}_{3}$ in a cell system does not necessarily preclude its role in directly modulating membrane currents. Whether $\operatorname{Ins}_{3} \mathrm{P}_{3}$ directly activates ion channels in the plasma membrane remains controversial (Irvine, 1987; Matthews et al., 1989). My results of Figures 7 and 8 show evidence that the membrane current changes induced by $\mathrm{InsP}_{3}$ injection in Aplysia nerve cells may be primary and are not due solely to a $\mathrm{Ca}_{i}$ increase. I cannot rule out that InsP may be converted to InsP $\mathrm{P}_{4}$ or some other messenger that itself would induce changes in membrane currents (but see Snyder et al., 1988). Some differences in the time course of the responses to both compounds are expected since $\mathrm{InsP}_{3}$ and $\mathrm{Ca}^{2+}$ do not probably have the same diffusion rate; $\mathrm{InsP}_{3}$ could diffuse less freely to the membrane, but $\mathrm{Ca}^{2+}$ would be strongly buffered.
One difference could be that the area of the membrane reached by $\operatorname{Ins}_{3}$ (if it is not rapidly degraded) is probably larger than the one reached by a point injection of $\mathrm{Ca}^{2+}$. It seems more likely, however, that $\operatorname{Ins}_{3}$ (or one of its products), in addition to mobilizing $\mathrm{Ca}^{2+}$ from intracellular stores, directly activates a conductance change in the membrane. A strong evidence is that the Ins $\mathrm{P}_{3}$-induced inward current is resistant to BAPTA, whereas the $\mathrm{Ca}$-induced outward current is not (Fig. 8). The fact that BAPTA is almost without effect on the Ins $\mathrm{P}_{3}$-induced membrane current excludes the possibility that it is the InsP $\mathrm{P}_{3}$-induced $\mathrm{Ca}_{i}$ increase that activates a membrane current change. Scholz et al. (1988) also found that $\mathrm{Ca}^{2+}$ injections do not mimic InsP $\mathbf{P}_{3}$ injections in Aplysia neurons, but their injections were made from separate micropipettes, and hence not necessarily at the same site. In oocytes, Parker and Ivorra (1990a) found that injections of Ins $_{3}$ or $\mathrm{Ca}^{2+}$ induce a chloride conductance; however, $\mathrm{Ca}^{2+}$ injection induced a larger $\mathrm{Ca}_{i}$ increase than $\operatorname{InsP}_{3}$, but a smaller membrane current change.

There are several reports of similar effects of $\mathrm{Ca}^{2+}$ and $\mathrm{InsP}_{3}$ injections on membrane currents (Sawada et al., 1987; Fink et al., 1988). I have seen no evidence of an effect of preinjecting one compound on the response to the second compound, even at short time intervals; however, I have not done a thorough time interval study. As shown on Figure 7, our typical procedure was to wait for the current induced by the first injection to reach baseline before making the second injection. It is therefore unlikely that the differences in current waveform between $\operatorname{InsP}_{3}$ and $\mathrm{Ca}^{2+}$-induced current changes are due to the effect of prior injection of InsP $\mathrm{P}_{3}$ on $\mathrm{Ca}^{2+}$-induced current changes or vice versa.

In conclusion, I was able to dissociate the $\mathrm{Ca}^{2+}$ mobilizing role of $\mathrm{InsP}_{3}$ from its direct action on the plasma membrane conductance. Furthermore, my results call for caution in using Ins $P_{3}$-induced ion current changes as an assay of intracellular free $\mathrm{Ca}^{2+}$ concentration changes (DeLisle et al., 1990; Komori and Bolton, 1991). It is clear as shown in this study and others that changes in membrane currents are not a faithful indicator of changes in $\mathrm{Ca}_{i}$.

\section{References}

Adams WB (1985) Slow depolarizing and hyperpolarizing currents which mediate bursting in Aplysia neurone R15. J Physiol (Lond) 360:51-68.

Adams WB, Levitan IB (1985) Voltage and ion dependences of the slow currents which mediate bursting in Aplysia neurone R15. J Physiol (Lond) 360:69-93.

Adler EM, Augustine GJ, Duffy SN, Charlton MP (1991) Alien intracellular calcium chelators attenuate neurotransmitter release at the squid giant synapse. J Neurosci 11:1496-1507.

Berridge MJ (1989) Inositol 1,4,5-trisphosphate-induced Ca mobilization is localized in Xenopus oocytes. Proc R Soc Lond [Biol] 238: 235-243.

Berridge MJ, Irvine RF (1989) Inositol phosphates and cell signalling Nature 341:197-205.

Coggeshall RE (1967) A light and electron microscope study of the abdominal ganglion of Aplysia californica. J Neurophysiol 30:12631287.

Corson DW, Fein A (1983) Quantitative pressure injection of picoliter volumes into Limulus photoreceptors. Biophys J 44:299-304.

DeLisle S, Krause K-H, Denning G, Potter BVL, Welsh MJ (1990) Effect of inositol trisphosphate and $\mathrm{Ca}^{2+}$ on oscillating elevations of $\mathrm{Ca}_{\mathrm{i}}$ in Xenopus oocytes. J Biol Chem 265:11726-11730.

Eberhard DA, Holz RW (1988) Intracellular Ca activates phospholipase C. Trends Neurosci 11:518-520.

Finch EA, Turner TJ, Goldin SM (1991) Calcium as coagonist of inositol 1,4,5-trisphosphate-induced calcium release. Science 252:443446.

Fink LA, Connor JA, Kaczmarek LK (1988) Inositol trisphosphate 
releases intracellularly stored calcium and modulates ion channels in molluscan neurons. J Neurosci 8:2544-2555.

Frank TM, Fein A (1991) The role of the inositol phosphate cascade in visual excitation of invertebrate microvillar photoreceptors. J Gen Physiol 97:697-723.

Frazier WT, Kandel ER, Kupferman I, Waziri R, Coggeshall RE (1967) Morphological and functional properties of identified cells in the abdominal ganglion of Aplysia californica. J Neurophysiol 30:12881351 .

Gawler DJ, Potter BVL, Nahorski SR (1990) Inositol 1,3,4,5-tetrakisphosphate-induced release of intracellular $\mathrm{Ca}^{2+}$ in SH-SY5Y neuroblastoma cells. Biochem J 272:519-524.

Gorman ALF, Hermann A (1979) Internal effects of divalent cations on potassium permeability in molluscan neurons. J Physiol (Lond) 296:395-410.

Gorman ALF, Hermann A, Thomas MV (1981) Intracellular calcium and the control of neuronal pacemaker activity. Fed Proc 40:22332239.

Gorman ALF, Levy S, Nasi E, Tillotson D (1984) Intracellular calcium measured with calcium-sensitive microelectrodes and arsenazo III in voltagc-clamped Aplysia neurones. J Physiol (Lond) 353:127-142.

Harootunian AT, Kao JPY, Paranjape S, Tsien RY (1991) Generation of $\mathrm{Ca}$ oscillations in fibroblasts by positive feedback between $\mathrm{Ca}$ and IP $_{3}$. Science 251:75-78.

Hofmeier G, Lux HD (1981) The time courses of intracellular free calcium and related electrical effects after injection of $\mathrm{CaCl}_{2}$ into neurons of the snail, Helix pomatia. Pfluegers Arch 391:242-251.

Irvine RF (1987) Inositol phosphates and calcium entry. Nature 328: 386.

Irvine RF, Moor RM (1986) Micro-injection of $\mathrm{IP}_{4}$ activates sea urchin eggs by a mechanism dependent on external $\mathrm{Ca}^{2+}$. Biochem $\mathrm{J}$ 240:917-920.

Komori S, Bolton TB (1991) Calcium release induced by inositol 1,4,5trisphosphate in single rabbit intestinal smooth muscle cells. J Physiol (Lond) 433:495-517.

Kramer RH, Zucker RS (1985a) Calcium-dependent inward current in Aplysia bursting pacemaker neurons. J Physiol (Lond) 362:107130.

Kramer RH, Zucker RS (1985b) Ca-induced inactivation of Ca current causes the interburst hyperpolarization of Aplysia bursting neurones. J Physiol (Lond) 362:131-160.

Levitan IB (1985) Phosphorylation of ion channels. J Membr Biol 87: 177-190.

Levitan IB, Harmar AJ, Adams WB (1979) Synaptic and hormonal regulation of a neuronal oscillator: a search for molecular mechanisms. J Exp Biol 81:131-151.

Levy S (1987) Intracellular injection of $\mathrm{IP}_{3}$ releases Ca from intracellular stores in Aplysia bursting neurons. Biophys J 51:424a.

Lcvy $S$ (1988) Effects of intracellular injection of inositol derivatives on $\mathrm{Ca}_{\mathrm{i}}$, bursting activity and membrane currents of molluscan neurons. J Gen Physiol 92:2a.

Levy $\mathrm{S}$ (1989) Differential effects of $\mathrm{IP}_{3}$ and $\mathrm{Ca}^{2+}$ injections on membrane currents of Aplysia neurons. Biophys J 55:436a.

Levy S, Fein A (1985) Relationship between light sensitivity and intracellular free $\mathrm{Ca}$ concentration in Limulus ventral photoreceptors: a quantitative study using Ca-selective microelectrodes. J Gen Physiol 85:805-841.

Levy S, Payne $\mathrm{R}$ (1991) Inhibition of the $\mathrm{IP}_{3}$-induced Ca release in Limulus ventral photoreceptors requires the continuous presence of elevated resting $\mathrm{Ca}_{1}$. Biophys J 59:531a.

Levy S, Tillotson D (1987) Ability of the $\mathrm{Ca}^{2+}$ selective electrode to measure fast and local $\mathrm{Ca}^{2+}$ transients in nerve cells. Can J Physiol Pharmacol 65:904-914.

Levy S, Tillotson D (1988) Effect of $\mathrm{Na}$ and $\mathrm{Ca}$ gradients on intracellular free $\mathrm{Ca}$ in voltage clamped Aplysia neurons. Brain Res 474: 333-342.

Matthews G, Neher E, Penner R (1989) $\mathrm{Cl}^{-}$conductance activated by external agonists and internal messengers in rat peritoneal mast cells. J Physiol (Lond) 418:131-144.

Meech RW (1974) The sensitivity of Helix aspersa neurones to injected calcium ions. J Physiol (Lond) 237:259-277.

Meyer T, Holowka D, Stryer L (1988) Highly cooperative opening of Ca channels by $\mathrm{IP}_{3}$. Science 240:653-656.

Michell RH (1975) Inositol phospholipids and cell surface receptor function. Biochem Biophys Acta 415:81-147.

Munoz J-L, Deyhimi F, Coles JA (1983) Silanization of glass in the making of ion-selective microelectrodes. J Neurosci Methods 8:231247

Oehme M, Kessler M, Simon W (1976) Neutral carrier $\mathrm{Ca}^{2+}$ microelectrode. Chimia 30:204-206.

Parker I, Ivorra I (1990a) Inhibition by $\mathrm{Ca}^{2+}$ of inositol trisphosphatemediated $\mathrm{Ca}^{2+}$ liberation: a possible mechanism for oscillatory release of $\mathrm{Ca}^{2+}$. Proc Natl Acad Sci USA 87:260-264.

Parker I, Ivorra I (1990b) Localized all-or-none calcium liberation by inositol triphosphate. Science 250:977-979.

Parker I, Miledi R (1989) Nonlinearity and facilitation in phosphoinositide signalling studied by the use of caged inositol trisphosphate in Xenopus oocytes. J Neurosci 9:4068-4077.

Parker I, Yao Y (1992) Regenerative release of calcium from functionally discrete subcellular stores by inositol trisphosphate. Proc R Soc Lond [Biol] 246:269-274.

Payne R (1991) Injection of 1 mM EGTA reverses desensitization of inositol trisphosphate-induced calcium release in Limulus photoreceptors. Biophys J 59:540a.

Payne R, Fein A (1987) Inositol 1,4,5 trisphosphate releases calcium from specialized sites within Limulus photoreceptors. J Cell Biol 104 933-937.

Payne R, Walz B, Levy S, Fein A (1988) The localization of Ca release by inositol trisphosphate in Limulus photoreceptors and its control by negative feedback. Philos Trans $\mathrm{R}$ Soc Lond [Biol] 320:359-379.

Payne R, Flores TM, Fein A (1990) Feedback inhibition by calcium limits the release of calcium by inositol trisphosphate in Limulus ventral photoreceptors. Neuron 4:547-555.

Putney JW Jr (1986) A model for receptor-regulated Ca entry. Cell Calcium $7: 1-12$

Sawada M, Ichinose M, Maeno T (1987) Ionic mechanism of the outward current induced by intracellular injection of inositol trisphosphate into Aplysia neurons. J Neurosci 7:1470-1483.

Scholz KP, Cleary LJ, Byrne JH (1988) Inositol 1,4,5 trisphosphate alters bursting pacemaker activity in Aplysia neurons: voltage-clamp analysis of effects on calcium currents. J Neurophysiol 60:86-104.

Smith TG Jr (1980) Ionic conductances in bursting pacemaker cells and their hormonal modulation. Cold Spring Harbor Rep Neurosci $1: 135-143$

Snyder P, Krause K, Welsh M (1988) Inositol trisphosphate isomers, but not inositol 1,3,4,5-tetrakisphosphate, induce calcium influx in Xenopus laevis oocytes. J Biol Chem 263:11048-11051.

Strong JA, Fox AP, Tsien RW, Kaczmarek LK (1987) Stimulation of protein kinase $\mathrm{C}$ recruits covert calcium channels in Aplysia bag cell neurons. Nature 325:714-717.

Swandulla D, Lux HD (1985) Activation of a nonspecific cation conductance by intracellular Ca elevation in bursting pacemaker neurons of Helix pomatia. J Neurophysiol 54:1430-1443.

Takemura H, Putney JW Jr (1989) Capacitative Ca entry in parotid acinar cells. Biochem J 258:409-412.

Thomas MV, Gorman ALF (1977) Internal calcium changes in a bursting pacemaker neuron measured with arsenazo III. Science 196: $531-533$.

Tillotson D (1979) Inactivation of Ca conductance dependent on entry of $\mathrm{Ca}^{2+}$ ions in molluscan neurons. Proc Natl Acad Sci USA 76:14971500 .

Tillotson D, Gorman ALF (1980) Non-uniform $\mathrm{Ca}^{2+}$ buffer distribution in a nerve cell body. Nature 286:816-817. 